Article

\title{
Effect of Viewing Real Forest Landscapes on Brain Activity
}

\author{
Chorong Song ${ }^{1,2,+} \mathbb{D}$, Harumi Ikei ${ }^{2,+}\left(\mathbb{D}\right.$, Takahide Kagawa ${ }^{3} \mathbb{D}$ and Yoshifumi Miyazaki ${ }^{2, *(\mathbb{D})}$ \\ 1 Department of Forest Resources, Kongju National University, 54 Daehak-ro, Yesan-eup, Yesan-gun, \\ Chungcheongnam-do 32439, Korea; crsong@kongju.ac.kr \\ 2 Center for Environment, Health and Field Sciences, Chiba University, 6-2-1 Kashiwa-no-ha, Kashiwa, \\ Chiba 277-0882, Japan; hikei@chiba-u.jp \\ 3 Forestry and Forest Products Research Institute, 1 Matsunosato, Tsukuba, Ibaraki 305-8687, Japan; \\ kagawa@ffpri.affrc.go.jp \\ * Correspondence: ymiyazaki@faculty.chiba-u.jp; Tel.: +81-4-7137-8184; Fax: +81-4-7137-8008 \\ + These authors contribute equally to this work.
}

Received: 20 July 2020; Accepted: 12 August 2020; Published: 14 August 2020

\begin{abstract}
Benefits related to health promotion by getting closer to forests have received increasing attention in modern stressful society; however, evidence-based research about how our brain activity changes when we stay in a forest environment is limited. Thus, the goal of this study was to evaluate the influence of viewing real forest landscapes on the activity in the prefrontal cortex area of young women's brains. The experiment included 29 women (age: $21.0 \pm 1.4$ years) and was executed in five forest and five urban areas. The participants stayed in the forest and urban areas and viewed each view for $15 \mathrm{~min}$. While viewing scenery, they had the oxyhemoglobin (oxy-Hb) concentrations in the left and right areas of their prefrontal cortexes measured continuously. Viewing real forest landscapes was associated with a significantly lower oxy-Hb concentration in the right area of the prefrontal cortex than when seeing urban areas. In conclusion, viewing real forest landscapes substantially diminished oxy- $\mathrm{Hb}$ concentrations in the right area of the prefrontal cortex, which is linked to physiological relaxation.
\end{abstract}

Keywords: forest therapy; cerebral activity; near-infrared spectroscopy; physical relaxation; stress recovery; preventive medicine

\section{Introduction}

According to a report by the United Nations, by $2050,68 \%$ of the worldwide population may be living in cities. This represents a dramatic and rapid increase over a short period of time; only $33 \%$ of the global population resided in urban areas in 1950 [1]. This degree of urbanization, which has proceeded very rapidly from an evolutionary perspective, has altered the environment in various ways; among these, individuals who reside in urban areas experience fewer natural environments and intensified vehicular traffic, as well as air and water pollution [2]. Furthermore, the ravages of climate change [3] currently threaten human life on Earth.

We have also experienced rapid changes that include the widespread use of computers and the development of mobile information and communication technologies (ICT), particularly the extensive use of smartphones. In 1984, Craig Brod [4] coined the term "technostress" to describe environments in which individuals are exposed to increasingly artificial and complicated environments that contribute to increasing levels of stress. Today, problems associated with ICT technology are emerging [5]; among these is nomophobia, which is the fear of being out of contact with one's mobile phone.

Due to conditions associated with the urbanization and artificialization that developed rapidly after the Industrial Revolution, modern societies are busier, more complicated, and highly-competitive 
environments. Many individuals remain primarily indoors and do not participate in physical activities. Nature-deficit disorder associated with urbanization has developed into a significant social problem. This disorder has become more prominent given that adults and, even more so, children are spending less time outdoors than their counterparts in previous generations [6]. There are some who believe that this environmental change has led to a wide range of behavioral problems. These recently-developed characteristics of modern society can result in serious stress, thereby increasing the risk of developing serious health problems [7-10]. As such, methods that can effectively relieve stress and induce physical and mental relaxation are needed. Stress relief that results from interactions with nature, particularly with forests, has been the focus of significant research; recent studies report that these interactions have an important and positive effect on human health [11-15]. Current scientific evidence has helped to establish the field of forest therapy, which is an evidence-based method used to promote human health via an experience known as "forest bathing". This experience is facilitated by the recognition of various elements that are characteristic of forest environments, including sensations associated with scent, scenery, and sound. The overall experience serves as a means to induce a state of physical relaxation and to bolster immune function in order to provide a strong defense against disease [11,13].

Previous research has examined the many health benefits associated with interactions with forest environments, including physical relaxation and reduced levels of stress. A brief walk through a forest or taking the opportunity to view forest scenery has been associated with decreased cortisol levels as well as decreased blood pressure and pulse rate. These activities serve to increase the activity of the parasympathetic nervous system, which results in increased comfort and relaxation; they also suppress the activity of the sympathetic nervous system, thereby limiting sensations of arousal and modulating stressful situations [16-26]. Moreover, forest therapy has been associated with improved immune function, with a measurable impact lasting up to one month [27-29].

There are very few studies that have focused on the effects of forest therapy on brain activity. In this study, and in those performed previously, changes in brain activity while experiencing a forest environment were measured via an evaluation of the hemoglobin concentration in the prefrontal cortex. The prefrontal cortex is the area of the brain that is responsible for higher functions, including problem-solving and decision-making. As such, changes in the oxygen and dioxygen hemoglobin concentrations in the prefrontal cortex may be especially useful in attempts to understand changes in brain activity. Park et al. [30] have observed that a brief walk in a forest environment resulted in reductions in the total hemoglobin concentration in the left area of the prefrontal cortex more than similar activities undertaken in urban areas. Likewise, Joung et al. [31] noted that the visualization of forest scenery from an urban rooftop also results in a decrease in total hemoglobin and oxy-hemoglobin concentrations in the prefrontal cortex compared with responses detected in response to views of urban scenery. However, these studies have limitations, including small sample sizes and evaluations performed with male participants only.

This study aimed to evaluate the impact of experiencing a forest environment and viewing forest landscapes on brain activity and to compare these results directly with similar activities undertaken in an urban setting.

\section{Materials and Methods}

\subsection{Experimental Sites and Study Period}

We conducted this study during 2014 to 2015 in five forest and urban areas of Japan. The forest areas were safe and well-maintained, and the urban landscapes were situated in downtown areas. We conducted all experiments during the summer from July to September. Details of the experiment sites are summarized in Table 1. 
Table 1. Details of the experiment sites.

\begin{tabular}{|c|c|c|c|c|c|}
\hline & 1 & 2 & 3 & 4 & 5 \\
\hline Location & $\begin{array}{l}\text { Iwate Town, Iwate } \\
\text { Prefecture }\end{array}$ & $\begin{array}{l}\text { Motosu City, } \\
\text { Gifu Prefecture }\end{array}$ & $\begin{array}{l}\text { Shiso City, Hyogo } \\
\text { Prefecture }\end{array}$ & $\begin{array}{c}\text { Daigo Town, Ibaraki } \\
\text { Prefecture }\end{array}$ & $\begin{array}{c}\text { Hakone Town, } \\
\text { Kanagawa Prefecture }\end{array}$ \\
\hline Dates & August 5, 6, 2014 & August 12, 13, 2014 & August 21, 22, 2014 & $\begin{array}{l}\text { August 6, 7, } \\
2015\end{array}$ & $\begin{array}{l}\text { September } 2,3 \\
2015\end{array}$ \\
\hline Forest Physiognomy & $\begin{array}{l}\text { Secondary forest } \\
\text { (red pine \& oak) and } \\
\text { artificial forest (larch) }\end{array}$ & $\begin{array}{l}\text { Secondary forest } \\
\text { (oak \& cherry) }\end{array}$ & $\begin{array}{l}\text { Secondary forest } \\
\text { (oak \& maple) }\end{array}$ & $\begin{array}{l}\text { Secondary forest } \\
\text { (red pine \& oak) }\end{array}$ & $\begin{array}{l}\text { Secondary forest } \\
\text { (red pine \& oak) }\end{array}$ \\
\hline Weather & $\begin{array}{l}\text { Day 1: sun } \\
\text { Day 2: sun }\end{array}$ & $\begin{array}{l}\text { Day 1: sun } \\
\text { Day 2: sun }\end{array}$ & $\begin{array}{l}\text { Day 1: sun } \\
\text { Day 2: rain }\end{array}$ & $\begin{array}{l}\text { Day 1: sun } \\
\text { Day 2: sun }\end{array}$ & $\begin{array}{l}\text { Day 1: rain } \\
\text { Day 2: cloud }\end{array}$ \\
\hline $\begin{array}{c}\text { Temperature }\left({ }^{\circ} \mathrm{C}\right) \\
\left(\text { mean } \pm \mathrm{SD}^{1}\right)\end{array}$ & $\begin{array}{c}\text { Forest: } 26.4 \pm 0.3 \\
\text { City: } 30.1 \pm 0.6\end{array}$ & $\begin{array}{c}\text { Forest: } 29.1 \pm 1.0 \\
\text { City: } 30.5 \pm 0.8\end{array}$ & $\begin{array}{c}\text { Forest: } 23.5 \pm 0.6 \\
\text { City: } 31.9 \pm 1.5\end{array}$ & $\begin{array}{c}\text { Forest: } 31.9 \pm 0.3 \\
\text { City: } 36.6 \pm 0.4\end{array}$ & $\begin{array}{c}\text { Forest: } 25.2 \pm 0.3 \\
\text { City: } 28.0 \pm 0.2\end{array}$ \\
\hline $\begin{array}{l}\text { Humidity (\%) } \\
\text { (mean } \pm \text { SD) }\end{array}$ & $\begin{array}{c}\text { Forest: } 84.9 \pm 1.5 \\
\text { City: } 63.6 \pm 2.8\end{array}$ & $\begin{array}{c}\text { Forest: } 74.4 \pm 4.1 \\
\text { City: } 66.5 \pm 5.7\end{array}$ & $\begin{array}{c}\text { Forest: } 93.5 \pm 2.3 \\
\text { City: } 54.9 \pm 3.9\end{array}$ & $\begin{array}{c}\text { Forest: } 60.7 \pm 1.3 \\
\text { City: } 45.0 \pm 1.1\end{array}$ & $\begin{array}{c}\text { Forest: } 78.9 \pm 2.9 \\
\text { City: } 69.4 \pm 1.4\end{array}$ \\
\hline $\begin{array}{c}\text { Illuminance (lx) } \\
\text { (mean) }\end{array}$ & $\begin{array}{l}\text { Forest: } 40 \\
\text { City: } 8920\end{array}$ & $\begin{array}{l}\text { Forest: } 4220 \\
\text { City: } 5590\end{array}$ & $\begin{array}{l}\text { Forest: } 70 \\
\text { City: } 6680\end{array}$ & $\begin{array}{l}\text { Forest: } 450 \\
\text { City: } 11,230\end{array}$ & $\begin{array}{l}\text { Forest: } 120 \\
\text { City: } 1360\end{array}$ \\
\hline
\end{tabular}

\subsection{Participants}

Twelve female Japanese university students participated in each group of experiments $(\mathrm{N}=60$ participants). Study participants were recruited via notices placed on bulletin boards at the university. The participants were primarily students with various major fields of study; no skews or biases were determined. Each student was paid 8800 JPY (about 80 USD) per day in exchange for their participation in the study. A history of physical or psychiatric disorder was not reported by any participant. The data of 20 participants with errors in data collection were excluded from the investigation, and the data of 11 participants who viewed the forest or urban areas while raining were excluded from the investigation. Thus, the analysis included the data of 29 participants (mean age \pm standard deviation: $21.0 \pm 1.4$ years). Mean height and weight were $158.1 \pm 4.8 \mathrm{~cm}$ and $50.5 \pm 6.4 \mathrm{~kg}$, respectively. The body mass index was $20.2 \pm 2.0 \mathrm{~kg} / \mathrm{m}^{2}$.

The study protocol was approved by the Ethics Committee of the Center for Environment, Health, and Field Sciences, Chiba University, Japan (project identification code number: 5). Before each experiment began, experimental procedures and the goals of the project were explained to participants and written informed consent was obtained. During each experiment, participants were not allowed to consume alcohol, tobacco, and caffeine.

\subsection{Experimental Procedures}

The experimental schedule is shown in Figure 1. To eliminate order effects, we randomly divided the participants into two groups ( $\mathrm{n}=6$ for each group). On day 1 , one group performed the experiment in the forest area, whereas the other performed the same experiment in an urban area. On day 2, the groups changed sites. The experiment was executed at a similar time to remove the influence of diurnal shifts on biological rhythms. 


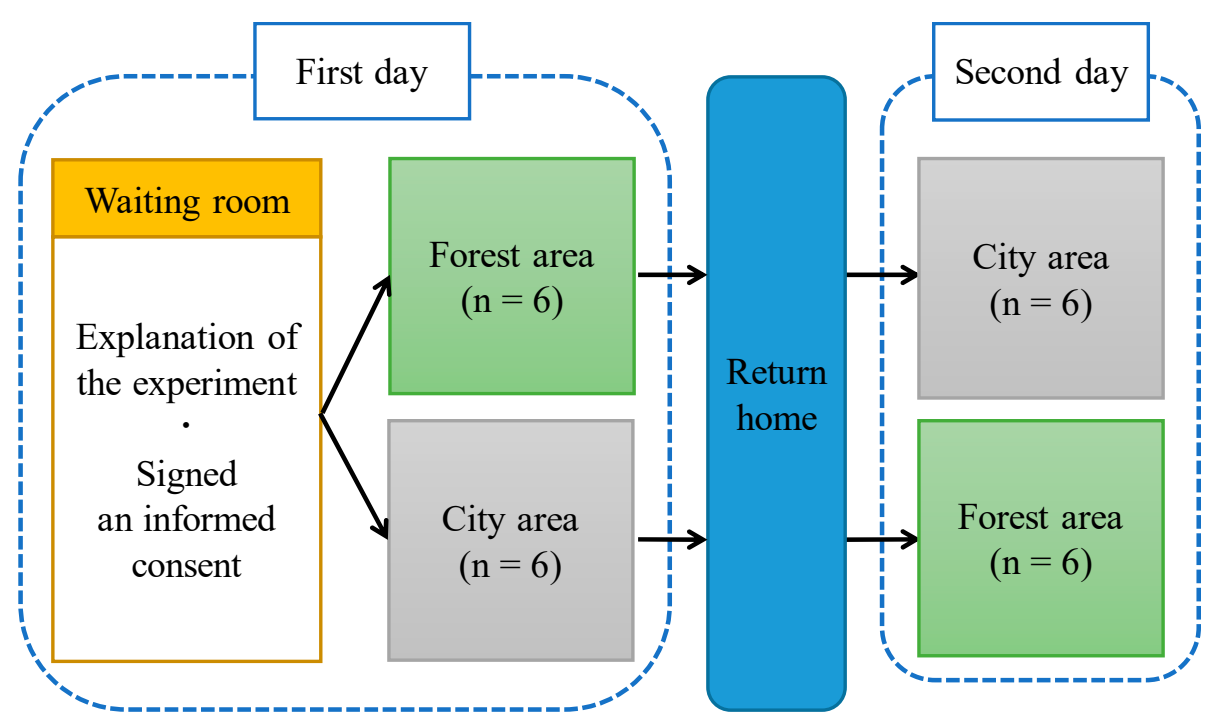

Figure 1. Schedule of the experiment.

After arriving at each field site, the participants waited for their turn inside a room, and each participant was eventually led to the experimental area and seated on a chair. The flow diagram of the study protocol in the experimental site is shown in Figure 2. Sensors for measurements were attached to the forehead. After the overall measurement flow was explained to the participants, they rested for $5 \mathrm{~min}$. During the rest period, the participants opened their eyes within the first $3 \mathrm{~min}$ and then closed them during the last $2 \mathrm{~min}$ to reduce the visual impact of both environments in the pre-measurement (baseline). As soon as the participants closed their eyes, a zero setting of physiological measurements was performed. After the last $2 \mathrm{~min}$, an experimenter instructed the participants to open their eyes. Then, the participants opened their eyes and viewed a forest or urban environment unfolding before their eyes across $15 \mathrm{~min}$ (Figure 3). During the $15 \mathrm{~min}$, brain activity was measured continuously.

NIRS measurements

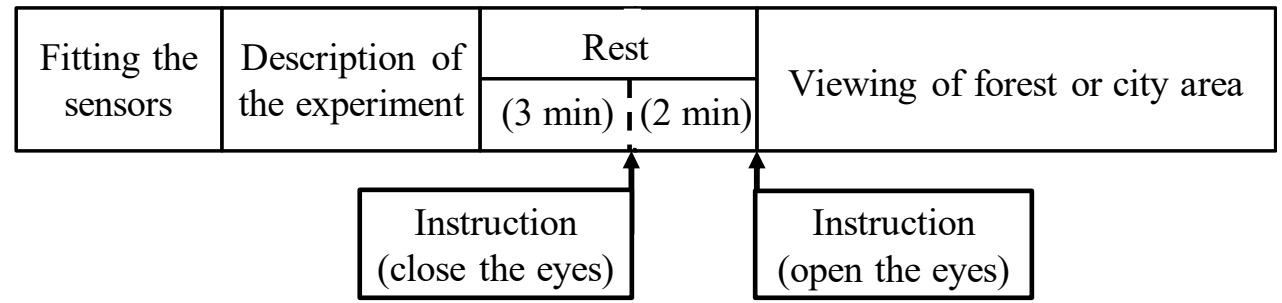

Figure 2. Flow of the study protocol. 


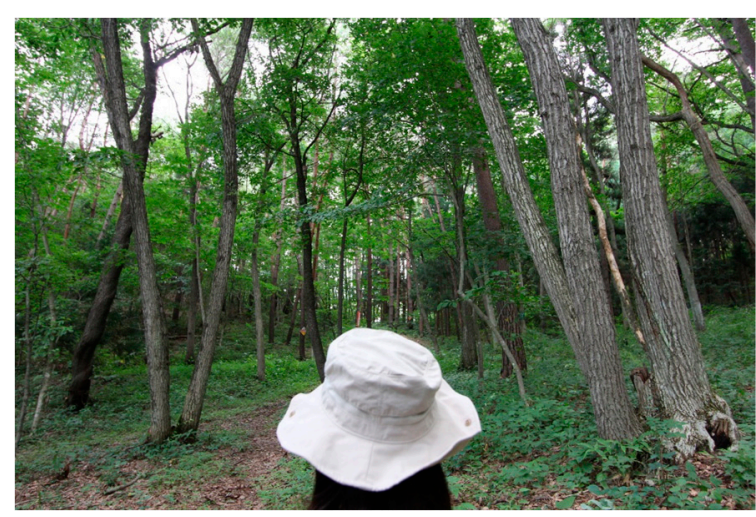

(a)

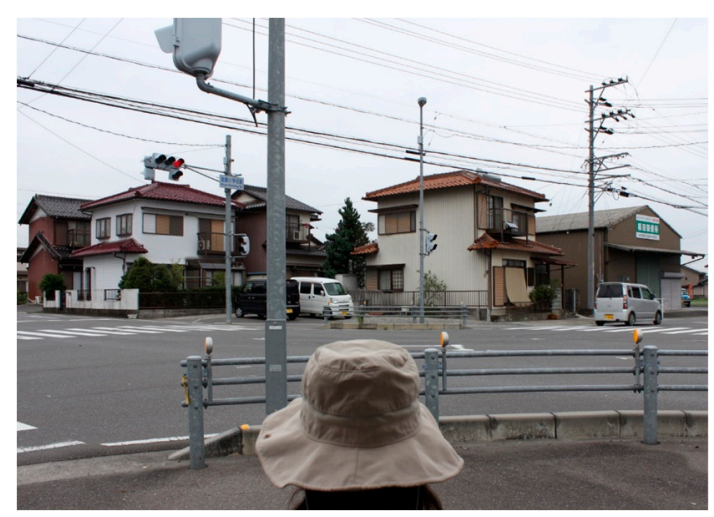

(b)

Figure 3. Viewing a forest (a) and an urban area (b).

\subsection{Measurement of Brain Activity}

Near-infrared spectroscopy (NIRS), which has proven reliability in the measurement of brain activity, was used. Shifts in oxy- $\mathrm{Hb}$ concentrations in the prefrontal cortex of the brain were assessed with a portable two-channel NIRS device operated at 735, 810, and $850 \mathrm{~nm}$ wavelengths (Pocket NIRS Duo, Dynasense, Hamamatsu, Japan) [32]. The prefrontal cortex is the area of the brain involved in a higher degree of judgments, including problem-solving and decision-making. The flexible NIRS probes were placed on each participant's forehead, and two sensors were located over the left and right frontal regions (Figure 4).

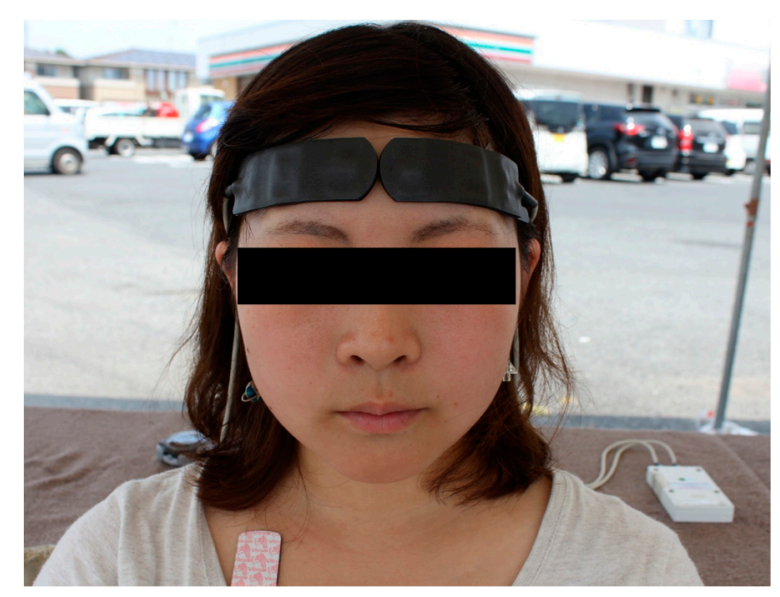

Figure 4. Portable near-infrared spectroscopy.

The basic tenets of NIRS measurement are as follows: When local brain activity increases, blood flow in the brain intensifies, leading to such marked perfusion that blood flow exceeds oxygen consumption [33]. As a result, oxy-Hb level rises, which can be determined by the change in the absorbance of near-infrared light irradiating the brain. In addition, changes (increases or decreases) in blood flow in the brain are similar to those of oxy- $\mathrm{Hb}$ [34].

The functional activation of the cerebral cortex related to oxygenation and hemodynamic changes can be examined using NIRS [35]. It is also known that NIRS signals are closely connected to functional magnetic resonance imaging measurements [36]. These findings support the notion that NIRS makes it possible to detect brain activity.

Across previous studies [37-39], forest-derived visual, olfactory, and auditory stimuli decreased oxy- $\mathrm{Hb}$ concentrations in the prefrontal cortex, and intensified subjective feelings of comfort and relaxation. These results indicate that forest-related stimuli decreased prefrontal cortex activity. 


\subsection{Data Analysis}

Data about the difference between viewing real forest and urban landscapes were used for analysis. All data were calculated as the difference from the mean value of the last $1 \mathrm{~min}$ of the rest period. The overall mean during the 15 -min viewing period was analyzed.

Statistical analysis was conducted with the Statistical Package for the Social Sciences software version 20.0 (IBM Corp., Armonk, NY, the USA). Paired t-tests were implemented to compare changes in prefrontal cortex activity between viewing real forest and urban landscapes. A $p$-value $<0.05$ was categorized as statistically significant. One-sided tests were chosen since viewing real forest landscapes was assumed to help the participant's stress recovery and relaxation.

\section{Results}

Figure 5 illustrates the time-dependent shifts in oxy- $\mathrm{Hb}$ concentration per second in the left and right areas of the prefrontal cortex while viewing forest and urban landscapes. The oxy- $\mathrm{Hb}$ concentrations gradually increased after the participants opened their eyes and during viewing the two landscapes. However, the oxy-Hb concentration across viewing of a forest was lower than that during viewing an urban area for $865 \mathrm{~s}$ out of $900 \mathrm{~s}$ in the left area of the prefrontal cortex (Figure 5a). In the right area of the prefrontal cortex, the oxy- $\mathrm{Hb}$ concentration when a participant viewed a forest was lower than during viewing an urban area for $880 \mathrm{~s}$ out of $900 \mathrm{~s}$ (Figure 5b).
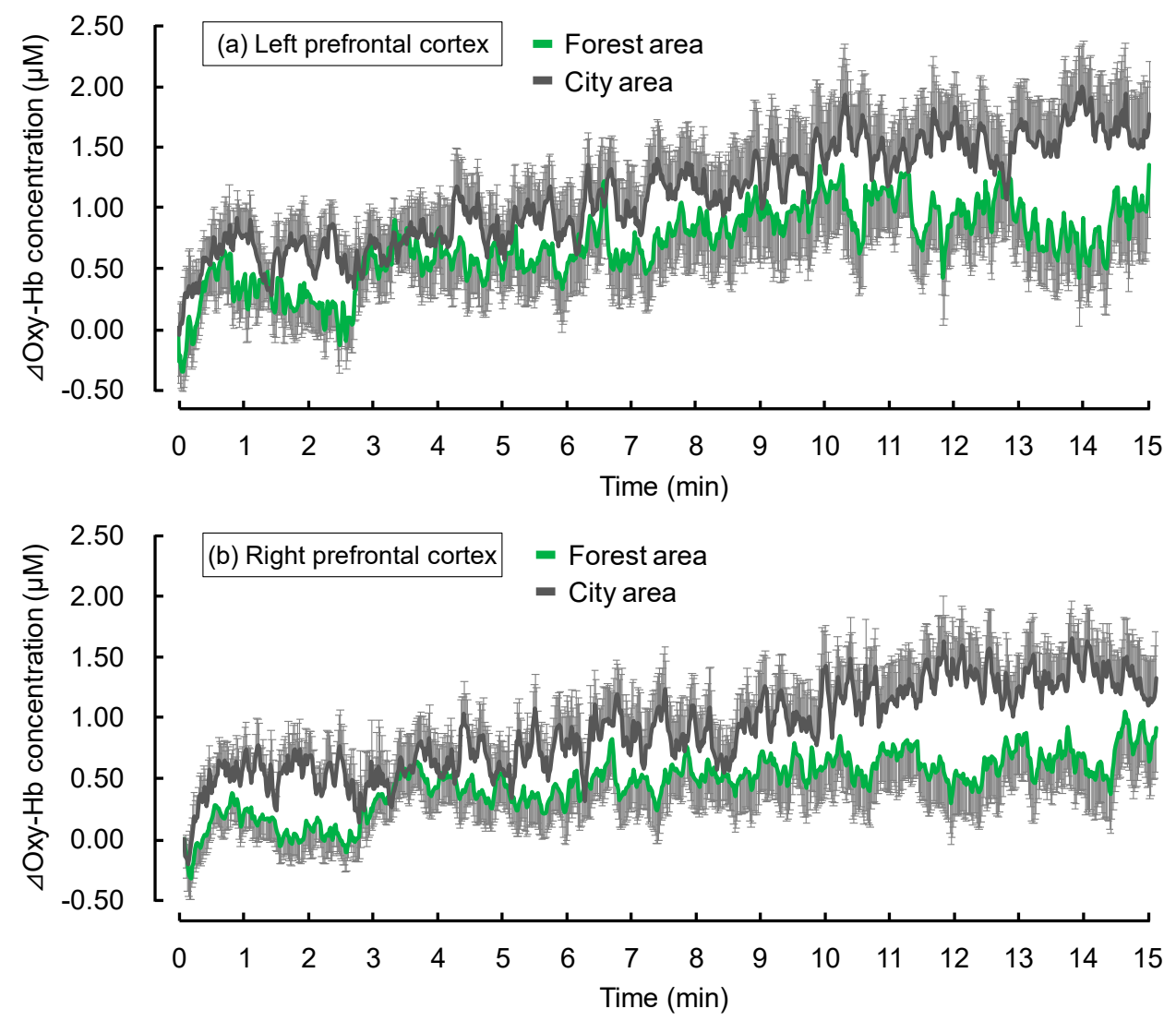

Figure 5. Changes in oxyhemoglobin $(\mathrm{oxy}-\mathrm{Hb})$ concentrations in the left and right areas of the prefrontal cortex across viewing of forest and urban areas. Data were delineated as mean \pm standard errors, $\mathrm{n}=29$.

The overall mean oxy-Hb concentrations in the left and right areas of the prefrontal cortex while viewing two landscapes are displayed in Figure 6. The mean oxy- $\mathrm{Hb}$ concentration in the right area of the prefrontal cortex during viewing a forest was lower than during viewing an urban area for 
$15 \min$ (forest: $0.46 \pm 0.19 \mu \mathrm{M}$ (mean \pm standard error); city: $0.90 \pm 0.20 \mu \mathrm{M} ; p<0.05$; Figure $6 \mathrm{~b}$ ). In the left area of the prefrontal cortex, the oxy- $\mathrm{Hb}$ concentration during viewing a forest was marginally significantly lower than during viewing an urban area (forest: $0.70 \pm 0.24 \mu \mathrm{M}$; city: $1.10 \pm 0.24 \mu \mathrm{M}$; $p<0.08$; Figure 6a).
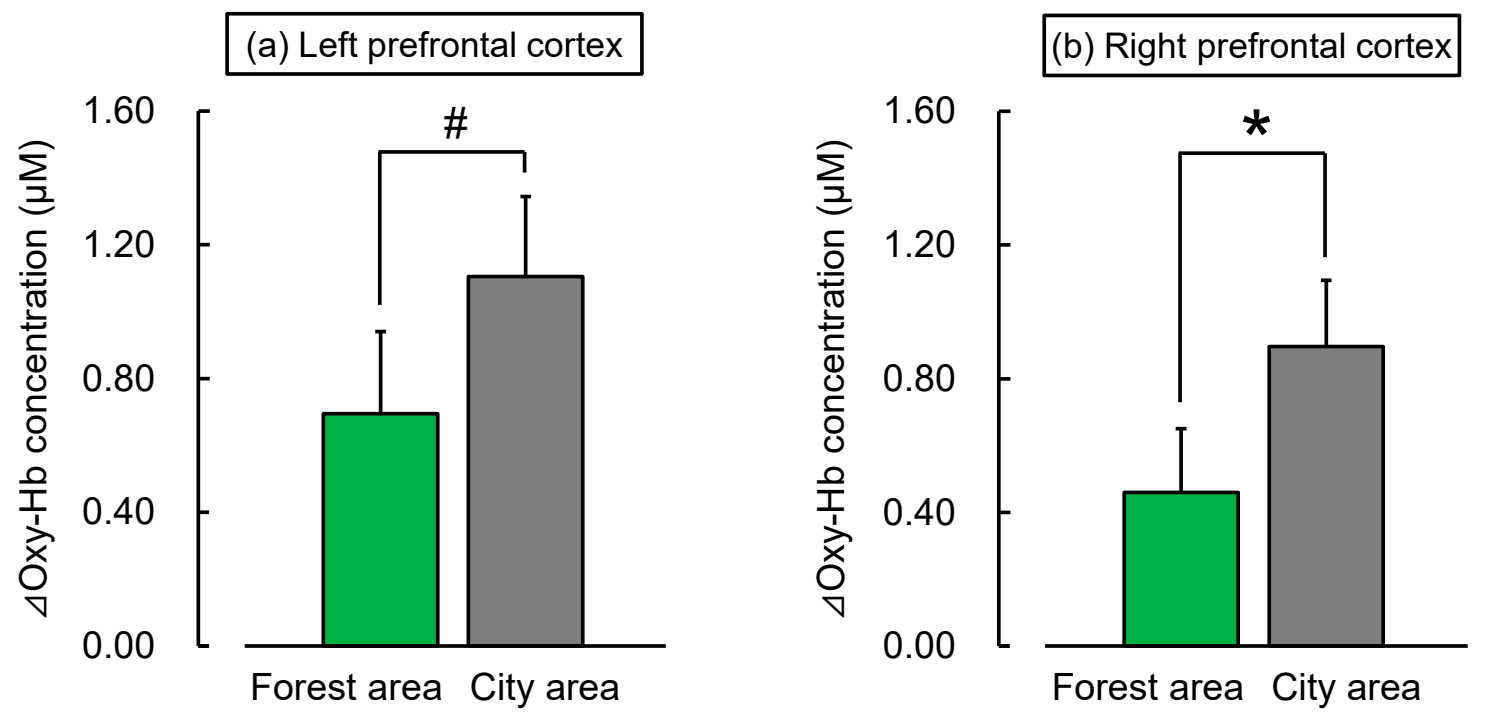

Figure 6. Overall mean oxyhemoglobin $(\mathrm{oxy}-\mathrm{Hb})$ concentration in the left and right areas of the prefrontal cortex across viewing of forest and urban areas. Data were delineated as mean \pm standard errors, $\mathrm{n}=29$. ${ }^{*} p<0.05$, $\# p<0.08$, as found using paired t-test (one-sided).

\section{Discussion}

The current study assessed the effect of viewing forest and urban landscapes on brain activity in young women. Viewing of forest landscapes significantly decreased prefrontal cortex activity compared with viewing urban environments.

Such a finding supports previous studies examining the effects of viewing a real forest landscape in men [30,31], and other previous studies [37-39] have shown the effect of forest-derived stimuli in women via laboratory experiments. Park et al. [30] have observed that a brief walk in a forest diminished the total hemoglobin concentration in the left area of the prefrontal cortex. Song et al. [39] have presented the effect of forest imagery using a large display on brain activity and revealed a reduction in oxy- $\mathrm{Hb}$ concentrations in the right area of the prefrontal cortex and an intensified perception of feeling comfortable, at ease, and unconstrained. Ikei et al. [37] have shown that the smell of Hinoki cypress (Chamaecyparis obtusa) diminishes oxy- $\mathrm{Hb}$ concentration in the right area of the prefrontal cortex. In addition, Jo et al. [38] have shown that the burbling of a woodland brook decreases oxy- $\mathrm{Hb}$ concentrations in the right area of the prefrontal cortex.

In the study by Park et al. [30], which included the element of exercise in male participants, a marked shift was observed in the activity of the left area of the prefrontal cortex; meanwhile, in the present and previous studies [37-39] that did not include the element of exercise in female participants, a marked shift was noted in the activity in the right area of the prefrontal cortex. The difference between the left and the right areas of prefrontal cortex activities is an important research topic. However, the mechanism associated with these activities is still not known; thus, future studies must compile additional information and validate the effect of natural stimuli on prefrontal cortex activity.

The results revealed that the mean oxy- $\mathrm{Hb}$ concentration during the viewing of a forest was lower than during the viewing of an urban area in the right area of the prefrontal cortex. In general, oxy- $\mathrm{Hb}$ is known to be strongly affected by changes in skin blood flow resulting from exercise and other factors [40]. However, the experiments were performed in a seated position without exercise in this experiment. In addition, both oxy- $\mathrm{Hb}$ and deoxyhemoglobin (deoxy- $\mathrm{Hb}$ ) concentrations change 
to the same direction when the skin blood flow changes. In this study, we confirmed the results that there is a decrease in deoxy- $\mathrm{Hb}$ concentrations in the context of the increase in oxy- $\mathrm{Hb}$. It suggests that there is no influence of changes in skin blood flow caused by movement or exercise. However, it is true that the changes in skin blood flow affect the NIRS signal; therefore, for future studies, we believe that we should measure NIRS signals and skin blood flow simultaneously.

Modern people constantly overexposed to various stressors and urban residents are at greater risk of health issues and increased mortality rates [7-10]. Management and prevention of stress are essential for health. Therefore, health benefits produced by forests are very important, and interaction with forests can offer effective opportunities for health promotion in modern life.

This study provided very important scientific evidence that viewing real forest landscapes sharply reduced oxy- $\mathrm{Hb}$ concentrations in the right area of the prefrontal cortex in young women. However, this study had several limitations. First, the participants were limited to healthy female university students who were in their 20s. Future studies involving male participants and participants of both sexes who are older will need to be considered. Second, because this study was performed at five independent sites, the results might include region-specific responses. As such, further examination of the impact of specific characteristics of the forests, including the amount of foliage, type, and location, must be included. These limitations should be considered when designing future research studies.

\section{Conclusions}

This study offered a key demonstration of the effects of viewing real forest landscapes versus urban areas on brain activity in young women. That is, viewing real forest landscapes substantially diminished oxy- $\mathrm{Hb}$ concentrations in the right area of the prefrontal cortex, which is linked to physiological relaxation.

Author Contributions: Conceptualization, Y.M.; methodology, C.S., H.I., T.K. and Y.M.; formal analysis, C.S.; investigation, C.S., H.I., T.K. and Y.M.; data curation, C.S., H.I., T.K. and Y.M.; writing-original draft preparation, C.S.; writing-review and editing, C.S. and Y.M.; visualization, C.S. and Y.M.; supervision, Y.M.; project administration, T.K. and Y.M. All authors have read and agreed to the published version of the manuscript.

Funding: This research received no external funding.

Acknowledgments: We appreciate Yuko Tsunetsugu of the University of Tokyo for providing support during the data collection phase of this study.

Conflicts of Interest: The authors declare no conflict of interest.

\section{References}

1. United Nations, the 2018 Revision of the World Urbanization Prospects. Available online: https://www.un. org/development/desa/en/news/population/2018-revision-of-world-urbanization-prospects.html (accessed on 10 April 2020).

2. Pronczuk, J.; Surdu, S. Children's environmental health in the twenty-first century. Ann. N. Y. Acad. Sci. 2008, 1140, 143-154. [CrossRef]

3. Patz, J.A.; Campbell, L.D.; Holloway, T.; Foley, J.A. Impact of regional climate change on human health. Nature 2005, 438, 310-317. [CrossRef] [PubMed]

4. Brod, C. Technostress: The Human Cost of the Computer Revolution; Addison Wesley: Boston, MA, USA, 1984.

5. SecurEnvoy. $66 \%$ of the Population Suffer from Nomophobia the Fear of Being without Their Phone. Available online: http://www.securenvoy.com/blog/2012/02/16/66-of-the-population-suffer-from-nomophobia-thefear-of-being-without-their-phone/ (accessed on 15 July 2020).

6. Louv, R. Last Child in the Woods: Saving Our Children from Nature Deficit Disorder; Algonquin Books: Chapel Hill, NC, USA, 2005.

7. Tanaka, A.; Takano, T.; Nakamura, K.; Takeuchi, S. Health levels influenced by urban residential conditions in a megacity-Tokyo. Urban Stud. 1996, 33, 879-894. [CrossRef]

8. Peen, J.; Schoevers, R.A.; Beekman, A.T.; Dekker, J. The current status of urban-rural differences in psychiatric disorders. Acta Psychiatr. Scand. 2010, 121, 84-93. [CrossRef] [PubMed] 
9. Lederbogen, F.; Kirsch, P.; Haddad, L.; Streit, F.; Tost, H.; Schuch, P.; Wüst, S.; Pruessner, J.C.; Rietschel, M.; Deuschle, M. City living and urban upbringing affect neural social stress processing in humans. Nature 2011, 474, 498-501. [CrossRef] [PubMed]

10. McKenzie, K.; Murray, A.L.; Booth, T. Do urban environments increase the risk of anxiety, depression and psychosis? An epidemiological study. J. Affect. Disord. 2013, 150, 1019-1024. [CrossRef] [PubMed]

11. Song, C.; Ikei, H.; Miyazaki, Y. Physiological effects of nature therapy: A review of the research in Japan. Int. J. Environ. Res. Public Health 2016, 13, 781. [CrossRef]

12. Hansen, M.M.; Jones, R.; Tocchini, K. Shinrin-Yoku (forest bathing) and nature therapy: A state-of-the-art review. Int. J. Environ. Res. Public Health 2017, 14, 851. [CrossRef]

13. Miyazaki, Y. Shinrin Yoku: The Art of Japanese Forest Bathing; Octopus Publishing Group: London, UK, 2018; p. 192.

14. Doimo, I.; Masiero, M.; Gatto, P. Forest and wellbeing: Bridging medical and forest research for effective forest-based initiatives. Forests 2020, 11, 791. [CrossRef]

15. Cervinka, R.; Schwab, M.; Haluza, D. Investigating the qualities of a recreational forest: Findings from the cross-sectional Hallerwald case study. Int. J. Environ. Res. Public Health 2020, 17, 1676. [CrossRef]

16. Tsunetsugu, Y.; Park, B.J.; Ishii, H.; Hirano, H.; Kagawa, T.; Miyazaki, Y. Physiological effects of Shinrin-Yoku (taking in the atmosphere of the forest) in an oldgrowth broadleaf forest in Yamagata Prefecture, Japan. J. Physiol. Anthropol. 2007, 26, 135-142. [CrossRef] [PubMed]

17. Park, B.J.; Tsunetsugu, Y.; Ishii, H.; Furuhashi, S.; Hirano, H.; Kagawa, T.; Miyazaki, Y. Physiological effects of Shinrin-yoku (taking in the atmosphere of the forest) in a mixed forest in Shinano Town, Japan. Scand. J. For. Res. 2008, 23, 278-283. [CrossRef]

18. Lee, J.; Park, B.J.; Tsunetsugu, Y.; Kagawa, T.; Miyazaki, Y. Restorative effects of viewing real forest landscapes, based on a comparison with urban landscapes. Scand. J. For. Res. 2009, 24, 227-234. [CrossRef]

19. Park, B.J.; Tsunetsugu, Y.; Kasetani, T.; Morikawa, T.; Kagawa, T.; Miyazaki, Y. Physiological effects of forest recreation in a young conifer forest in Hinokage Town, Japan. Silva Fenn. 2009, 43, 291-301. [CrossRef]

20. Park, B.J.; Tsunetsugu, Y.; Kasetani, T.; Kagawa, T.; Miyazaki, Y. The physiological effects of Shinrin-yoku (taking in the forest atmosphere or forest bathing): Evidence from field experiments in 24 forests across Japan. Environ. Health Prev. Med. 2010, 15, 18-26. [CrossRef]

21. Lee, J.; Park, B.J.; Tsunetsugu, Y.; Ohira, T.; Kagawa, T.; Miyazaki, Y. Effect of forest bathing on physiological and psychological responses in young Japanese male subjects. Public Health 2011, 125, 93-100. [CrossRef]

22. Park, B.J.; Tsunetsugu, Y.; Lee, J.; Kagawa, T.; Miyazaki, Y. Effect of the forest environment on physiological relaxation-the results of field tests at 35 sites throughout Japan. In Forest Medicine; Li, Q., Ed.; Nova Science Publishers, Inc.: New York, NY, USA, 2012; pp. 55-65.

23. Tsunetsugu, Y.; Lee, J.; Park, B.J.; Tyrväinen, L.; Kagawa, T.; Miyazaki, Y. Physiological and psychological effects of viewing urban forest landscapes assessed by multiple measurements. Landsc. Urban Plan. 2013, 113, 90-93. [CrossRef]

24. Lee, J.; Tsunetsugu, Y.; Takayama, N.; Park, B.J.; Li, Q.; Song, C.; Komatsu, M.; Ikei, H.; Tyrväinen, L.; Kagawa, T.; et al. Influence of forest therapy on cardiovascular relaxation in young adults. Evid. Based Complement. Alternat. Med. 2014, 2014, 834360. [CrossRef]

25. Song, C.; Ikei, H.; Kagawa, T.; Miyazakia, Y. Effects of walking in a forest on young women. Int. J. Environ. Res. Public Health 2019, 16, 229. [CrossRef]

26. Song, C.; Ikei, H.; Kagawa, T.; Miyazakia, Y. Physiological and psychological effects of viewing forests on young women. Forests 2019, 10, 635. [CrossRef]

27. Li, Q.; Morimoto, K.; Nakadai, A.; Inagaki, H.; Katsumata, M.; Shimizu, T.; Hirata, Y.; Hirata, K.; Suzuki, H.; Miyazaki, Y.; et al. Forest bathing enhances human natural killer activity and expression of anti-cancer proteins. Int. J. Immunopathol. Pharmacol. 2007, 20, 3-8. [CrossRef] [PubMed]

28. Li, Q.; Morimoto, K.; Kobayashi, M.; Inagaki, H.; Katsumata, M.; Hirata, Y.; Hirata, K.; Suzuki, H.; Li, Y.J.; Wakayama, Y.; et al. Visiting a forest, but not a city, increases human natural killer activity and expression of anti-cancer proteins. Int. J. Immunopathol. Pharmacol. 2008, 21, 117-127. [CrossRef] [PubMed]

29. Li, Q.; Morimoto, K.; Kobayashi, M.; Inagaki, H.; Katsumata, M.; Hirata, Y.; Hirata, K.; Shimizu, T.; Li, Y.J.; Wakayama, Y.; et al. A forest bathing trip increases human natural killer activity and expression of anti-cancer proteins in female subjects. J. Biol. Regul. Homeost. Agents 2008, 22, 45-55. [PubMed] 
30. Park, B.J.; Tsunetsugu, Y.; Kasetani, T.; Hirano, H.; Kagawa, T.; Sato, M.; Miyazaki, Y. Physiological effects of Shinrin-Yoku (taking in the atmosphere of the forest)-using salivary cortisol and cerebral activity as indicators. J. Physiol. Anthropol. 2007, 26, 123-128. [CrossRef]

31. Joung, D.; Kim, G.; Choi, W.; Lim, H.; Park, S.; Woo, J.M.; Park, B.J. The prefrontal cortex activity and psychological effects of viewing forest landscapes in autumn season. Int. J. Environ. Res. Public Health 2015, 12, 7235-7243. [CrossRef]

32. Watanabe, T.; Mizuno, T.; Shikayama, T.; Miwa, M. Development of a wireless near infrared tissue oxygen monitor system with high sampling rate. In Digital Holography and Three-Dimensional Imaging; Optical Society of America: Miami, FL, USA, 2012.

33. Fox, P.T.; Raichle, M.E. Focal physiological uncoupling of cerebral blood flow and oxidative metabolism during somatosensory stimulation in human subjects. Proc. Natl. Acad. Sci. USA 1986, 83, 1140-1144. [CrossRef]

34. Hoshi, Y.; Kobayashi, N.; Tamura, M. Interpretation of near infrared spectroscopy signals: A study with a newly developed perfused rat brain model. J. Appl. Physiol. 2001, 90, 1657-1662. [CrossRef]

35. Ferrari, M.; Quaresima, V. A brief review on the history of human functional near-infrared spectroscopy (fNIRS) development and fields of application. NeuroImage 2012, 63, 921-935. [CrossRef]

36. Cui, X.; Bray, S.; Bryant, D.M.; Glover, G.H.; Reiss, A.L. A quantitative comparison of NIRS and fMRI across multiple cognitive tasks. NueroImage 2011, 54, 2808-2821. [CrossRef]

37. Ikei, H.; Song, C.; Miyazaki, Y. Physiological effect of olfactory stimulation by Hinoki cypress (Chamaecyparis obtusa) leaf oil. J. Physiol. Anthropol. 2015, 34, 44. [CrossRef]

38. Jo, H.; Song, C.; Ikei, H.; Enomoto, S.; Kobayashi, H.; Miyazaki, Y. Physiological and psychological effects of forest and urban sounds using high-resolution sound sources. Int. J. Environ. Res. Public Health 2019, 16, 2649. [CrossRef] [PubMed]

39. Song, C.; Ikei, H.; Miyazaki, Y. Physiological effects of visual stimulation with forest imagery. Int. J. Environ. Res. Public Health 2018, 15, 213. [CrossRef] [PubMed]

40. Miyazawa, T.; Horiuchi, M.; Komine, H.; Sugawara, J.; Fadel, P.J.; Ogoh, S. Skin blood flow influences cerebral oxygenation measured by near-infrared spectroscopy during dynamic exercise. Eur. J. Appl. Physiol. 2013, 113, 2841-2848. [CrossRef] [PubMed] 